\title{
PENGEMBANGAN MEDIA LAYANAN BIMBINGAN KELOMPOK BERBASIS LANDASAN HIDUP RELIGIUS BAGI SISWA SEKOLAH MENENGAH PERTAMA
}

\author{
Santy Andrianie, M.Pd \\ Program Studi Bimbingan dan Konseling, Universitas Nusantara PGRI Kediri \\ e-mail : sandrianie.putranto@gmail.com
}

\begin{abstract}
ABSTRAK
Penelitian pengembangann ini dilatarbelakangi oleh menurunnya angka kereligiusan remaja yang belum mendapatkan penanganan tepat. Tujuan penelitian ini adalah menghasilkan produk berupa media layanan bimbingan kelompok berbasis landasan hidup religius bagi siswa sekolah menengah pertama dan petunjuk penerapannya untuk guru yang efektif secara teoritis dan praktik. Model pengembangan yang digunakan mengadaptasi strateg Borg and Gall. Berdasarkan penilaian ahli dan calon pengguna dalam kelompok kecil, kedua produk dinilai memenuhi kriteria pengembangan berupa ketepatan, kegunaan, kemudahan dan kemenarikan serta memiliki tingkat keberterimaan cukup baik.
\end{abstract}

Kata Kunci : Bimbingan Kelompok, Landasan Hidup Religius, Sekolah

Menengah Pertama

\section{A. PENDAHULUAN}

Salah satu unsur kebudayaan yang pasti ada dalam suatu masyarakat yaitu adanya sistem kepercayaan atau religi. Jika dilihat dari arti, istilah religi yang diambil dari bahasa Latin religare mempunyai arti atau makna ikatan atau mengikat. Jika diamati, memang makna ini bisa dimengerti karena dalam religi manusia mengikatkan diri kepada Tuhan. Pada pokoknya religi adalah penyerahan diri kepada
Tuhan, dalam keyakinan bahwa manusia itu tergantung dari Tuhan, bahwa Tuhanlah keselamatan yang sejati dari manusia, bahwa manusia dengan ketakutannya sendiri tidak mampu untuk memperoleh keselamatan itu dan karenanya ia menyerahkan diri (Driyakarya dalam Purwadi, 2002).

Remaja merupakan salah satu unsur yang terdapat dalam suatu masyarakat, selain orang dewasa, usia lanjut dan anak-anak. Meskipun 
pada usia ini, remaja sering kali masih dianggap sebagai anak-anak namun sebenarnya para remaja telah mengalami perkembangan perubahan dari anak-anak menjadi usia yang lebih matang. Pengertian remaja secara sederhana adalah individu yang usianya berkisar kira-kira antara 13 tahun sampai 16 tahun untuk awal remaja dan akhir masa remaja bermula dari usia 16 atau 17 tahun sampai 18 tahun. (Hurlock, 1999). Perkembangan jiwa pada masa ini masih labil, meskipun secara biologis telah mencapai kematangan. Adapun istilah adolescence atau remaja, seperti yang digunakan saat ini, mempunyai arti yang lebih luas, mencakup kematangan mental, emosional, soial dan fisik.

Zakiah (dalam Jalaludin, 2005) menyatakan bahwa perkembangan jasmani dan rohani yang terjadi pada para remaja turut mempengaruhi perkembangan remajanya. Penghayatan para remaja terhadap ajaran agama dan tindak keagamaan yang tampak pada remaja banyak berkaitan dengan faktor perkembangan jasmani dan rohaninya.

Siswa sekolah menengah pertama (SMP) berada pada pada jenjang kehidupan remaja, hal ini mudah terlihat bila ditinjau dari usia mereka. Perilaku yang tampak juga mudah diamati, akan tampak berbeda bagaimana perilaku siswa SMPdengan siswa SMA, maupun dengan orang dewasa. Siswa SMA masih ingin bertindak atau berperilaku sesuka hatinya namun di lain pihak mareka masih harus mematuhi peraturan-peraturan yang ada di lingkungannya, baik di sekolah maupun dirumah.

Berdasarkan pengamatan terhadap perilaku religius siswa di sekolah dan wawancara dengan siswa serta guru, ditemukan fakta bahwa perilaku religius belum tercermin dalam kehidupan di sekolah. Fakta ini tampak pada kegiatan pembelajaran di mana tidak semua guru membuka kegiatan belajar dengan mengucapkan salam sesuai dengan keyakinannya. Ketika guru mengucapkan salam, tidak semua siswa menjawab. Masih banyak kegiatan belajar yang tidak 
dimulai dengan berdoa bersama untuk kelancaran kegiatan belajar siswa.

\section{Hasil}

wawancara

menunjukkan hasil yang tidak jauh berbeda. Siswa mengaku belum rutin melaksanakan ibadah sholat lima waktu. Mereka hanya melaksanakan ibadah sholat ketika disuruh oleh guru atau orangtua dan saat menjelang ujian sekolah. Mereka berdalih bahwa banyak temantemannya yang tidak sholat, bahkan mereka menceritakan bahwa orangtuanya juga jarang sholat. Mereka juga jarang mengucapkan salam saat berangkat ataupun pulang sekolah.

Fenomena yang tergambar menunjukkan bahwa perilaku peribadatan yang belum mandiri dari para siswa. Hal ini ditunjukkan dengan sikap siswa yang melakukan ibadah setelah disuruh oleh orang tua. Selain itu, pengaruh dari lingkungan, dari luar keluarga, yaitu teman-teman siswa juga memberikan pengaruh bagi kehidupan peribadatan siswa.

Disamping itu, tergambar bahwa siswa melakukan peribadatan sebagai bentuk permohonan atau doa kepada Tuhan agar mendapat kemudahan ketika menghadapi kesulitan, dalam hal ini adalah ketika siswa menjalani ujian. Jika ditinjau kembali sebenarnya nampak adanya kemandirian peribadatan dari siswa tersebut, namun terjadi gejala simpang arah.

Dari gambaran fenomena yang ada, dapat dilihat bahwa remaja cenderung lebih memilih pada sesuatu atau hal-hal yang menyenangkan (fun), Dalam artian bahwa dari kegiatan-kegiatan yang mereka lakukan bisa menimbulkan kesenangan yang dapat langsung mereka rasakan. Sedangkan ketika kita berbicara tentang kereligiusan (agama) maka kesenangan yang akan muncul merupakan sesuatu yang bisa dinikmati di masa yang akan datang.

Bimbingan konseling merupakan salah satu komponen pendidikan yang dapat berperan dalam peningkatan religius siswa. Media mempunyai kedudukan yang penting dalam proses pemberian layanan bimbingan dan konseling. Media tidak hanya sekedar alat bantu, tapi merupakan bagian 
integral dalam proses pemberian layanan bimbingan dan konseling, artinya kehadiran media mutlak diperlukan untuk membantu siswa.

Media adalah segala bentuk dan saluran yang dapat digunakan dalam suatu proses penyajian informasi (AECT ,1977). Pendapat ini mempertegas bahwa media mempunyai potensi sebagai penyalur dan menjelaskan pesan sehingga memudahkan siswa dalam menerima pesan tersebut.

Dalam penyampaian informasi pemilihan media yang tepat dan efektif dapat meciptakan interaksi siswa dengan konselor yang baik dan mempengaruhi efektivitas pemberian layanan. Proses pemberian layanan atau pemberian informasi dengan metode ceramah akan membuat siswa bosan dan tidak tersampaikannya pesan layanan atau materi dari guru dengan baik. Informasi yang didesain dengan media yang menarik diharapkan dapat menjadikan siswa tertarik untuk membacanya.

Peneliti memilih untuk mengembangkan media landasan hidup religius dengan berbagai pertimbangan, yaitu agama (kehidupan religius) sebagai landasan utama dalam berbagai aspek kehidupan. Tidak hanya sekedar moral yang menjadi urusan agama, akan tetapi hal- hal yang berkaitan dengan hukum dan undang-undang baik ekonomi, sosial maupun politik, diketahui bahwa agama menjadi pedoman dasarnya. Begitu juga dengan hal-hal lain seperti kesehatan, hubungan suami istri, perdagangan, pendidikan dan lain-lain semuanya telah ada dalam ajaran agama.

Dari penjelasan yang diberikan, maka diperlukan adanya media pemberian layanan bimbingan dan konseling dalam aspek kehidupan religius yang menjelaskan informasi-informasi tentang pentingnya landasan hidup religius (norma-norma agama) dalam berperilaku di kehidupan sehari-hari. Sehingga bisa memberikan suatu pola pikir baru bagi siswa bahwa dalam menjalankan agama dan kepercayaan kita juga akan menjadikan suatu kesenangan yang akan dinikmati di masa depan atau sebuah pandangan tentang agama 
sebagai investasi hidup. Media yang diharapkan adalah media yang memiliki kriteria ketepatan, kegunaan, kemudahan, dan kemenarik, sehingga siswa tidak merasa jenuh namun dengan penggunaan media tidak mengurangi interaksi antara siswa dan konselor dalam memberikan layanan. Berdasarkan uraian diatas peneliti melaksanakan penelitian dengan judul "Pengembangan Media Bimbingan Kelompok Berbasis Landasan Hidup Religius untuk Siswa SMP"

Adapun tujuan dari penelitian ini adalah merancang pesan-pesan yang perlu dipahami mengenai landasan hidup religius dalam suatu media bimbingan dan menghasilkan suatu media bimbingan yang dapat dipahami dan digunakan oleh siswa SMP.

Ruang lingkup penelitian ini hanya membahas mengenai konsep hidup religius sesuai dengan tugas perkembangan remaja. Selain itu, pengembangan media disesuaikan dengan tingkat usia pengguna yaitu pada jenjang remaja.
Penelitian ini mengadopsi model Reserch and Divelopment (R\&D) Borg and Gall (1983). Sasaran utama R\&D bukan merumuskan atau mengkaji teori tertentu, melainkan mengembangkan suatu produk tertentu untuk penggunaannya di sekolah. Siklus $\mathrm{R} \& \mathrm{D}$ mencakup penemuan penelitian terhadap produk yang akan dihasilkan, mengkajinya kembali dimana hasil tersebut digunakan dan merevisinya sampai kajian tersebut dianggap memadai. Pada penilitian pengembangan ini, peneliti hanya melakukan sampai tahap kelima, yaitu melakukan penelitian dan mengumpulkan informasi, melakukan perencanaan, mengembangkan bentuk produk awal, melakukan penilaian ahli terhadap produk dan uji coba lapangan, dan melakukan revisi produk utama.

Analisis data angka yang diperoleh dari penilaian ahli (ahli bimbingan dan konseling serta ahli media) dilakukan dengan analisis inter-rater agreement sesuai teori Gregory, (2011). Sementara data yang diperoleh dari calon pengguna 
dianalisis menggunakan persentase. Data kuantitatif dari calon pengguna berupa saran dan komentar dianalisis secara deskriptif untuk penyempurnaan media bimbingan kelompok berbasis landasan hidup religius untuk siswa SMP.

\section{B. PEMBAHASAN}

Frankl menyebutkan bahwa manusia memiliki dimensi spiritual yang terintegrasi dengan dimensi ragawi dan kejiwaan. Glock dan Stark (dalam Ancok D., 2005) melihat konsep religiusitas sebagai komitmen religius individu yang dapat dilihat melalui aktivitas atau perilaku individu yang bersangkutan terhadap agama atau iman kepercayaan yang dianutnya. Manusia mempunyai naluri beragama. Menurut Jalaluddin (2010) manusia merupakan makhluk beragama (homo religious). Uji coba pengembangan media bimbingan kelompok ini dilakukan dalam dua tahap. Tahap pertama adalah uji ahli dan tahap kedua uji calon pengguna dalam kelompok keci. Uji kelompok kecil dilakukan di dua sekolah dengan dua konselor dan 10 siswa dari masing-masing sekolah.

Ancok D. (2005) menjelaskan bahwa religiusitas diwujudkan dalam berbagai sisi kehidupan manusia, baik itu menyangkut perilaku ritual atau aktivitas lain dalam kehidupan sehari-harinya baik yang tampak dan bisa dilihat mata atau tidak tampak. Keberagamaan seseorang akan meliputi berbagai macam dimensi atau sisi. Dengan demikian agama adalah sebuah sistem yang berdimensi banyak. Glock dan Stark (dalam Subandi, 1997) menyatakan bahwa agama adalah simbol, sistem keyakinan, sistem nilai, dan sistem perilaku yang terlembagakan, yang semua ini berpusat pada persoalanpersoalan yang dihayati sebagai paling maknawi.

Menurut Ancok D. (2005) bahwa konsep religiusitas versi Glock dan Stark dapat melihat keberagamaan seseorang tidak hanya dari satu atau dua dimensi, tapi mencoba memperhatikan segala dimensi. Keberagamaan dalam Islam bukan hanya diwujudkan dalam bentuk ibadah ritual saja, tapi juga dalam aktivitas-aktivitas lainnya. 
Perilaku religius seseorang bukan merupakan bawaan lahir namun tumbuh dan dipengaruhi oleh lingkungannya. Sebagai salah satu lembaga pendidikan, sekolah memiliki pernanan dalam pembentukan perilaku pendidikan. Sekolah merupakan lembaga pendidikan formal yang mempunyai program yang sistematis dalam melaksanakan bimbingan, pembelajaran dan latihan kepada anak agar mereka mampu berkembang sesuai dengan potensinya. Menurut Hurlock (1999), sekolah merupakan subsitusi dari keluarga dan guru-guru merupakan subsitusi dari orang tua. Selain sebagai lembaga pengajaran, sekolah juga merupakan lembaga pendidikan bagi anak, yang tidak hanya memberikan materi teoritis, namun juga berperan dalam membentuk kepribadian dan perilaku siswa termasuk perilaku religius siswa.

Nursalim dan Mustaji (2010) menyatakan bahwa media bimbingan dan konseling adalah segala sesuatu yang dapat digunakan untuk menyalurkan pesan bimbingan dan konseling yang dapat merangsang pikiran, perasaan, perhatian, dan kemauan siswa/konseli untuk memahami diri, mengarahkan diri, mengambil keputusan serta memecahkan masalah yang dihadapi. Media bimbingan dan konseling selalu terdiri atas dua unsur penting, yaitu unsur peralatan atau perangkat keras (hardware) dan unsur pesan yang dibawanya (message/software).

Peranan media dalam layanan bimbingan dan konseling memiliki posisi yang penting. Melalui media, konselor dapat lebih mudah dalam melaksanakan layanannya dan siswa akan lebih tertarik untuk mengikuti layanan bimbingan dan konseling dibandingkan dengan metode ceramah.

Dalam penelitian ini media dikembangkan berdasarkan hasil analisis kebutuhan siswa untuk kemudian diperkuat dengan teoriteori yang mendasari. Kemudian media dikembangkan dengan memperhatikan kesesuaian dengan teori dan menambahkan animasi/gambar serta menggunakan bahasa yang lugas agar lebih mudah dipahami. Sebelum masuk pada tahap uji kelompok kecil, media 
terlebih dahulu melalui tahap penilaian ahli untuk kemudian direvisi agar siap untuk digunakan dalam uji kelompok kecil. Setelah dilakukan revisi berdasarkan penilaian ahli, maka media siap digunakan pada uji kelompok kecil untuk mendapatkan penilaian dan masukan. Penilaian dan masukan dari calon pengguna dalam uji kelompok kecil ini kemudian dijadikan sebagai dasar revisi penyempurnaan produk media dan buku petunjuk pelaksanaannya oleh guru BK.

Uji coba tahap pertama dilakukan untuk memperoleh data berupa penilaian, saran, tanggapan, kritik atau masukan dari ahli dan dapat digunakan sebagai dasar dalam memperbaiki produk pengembangan yang dihasilkan sebelum melaksanakan uji coba tahap kedua. Uji coba tahap kedua dilakukan untuk memperoleh data berupa saran, tanggapan, kritik atau masukan dari calon pengguna produk dan dapat digunakan sebagai dasar dalam memperbaiki produk yang dihasilkan.
Uji ahli bertujuan untuk menguji keseluruhan aspek dalam media bimbingan, baik validitas substansi media, maupun forma (bentuk) media dalam hal ketepatan, kegunaan, kemudahan, kemenarikan, kejelasan dan kelayakan media bimbingan yang dikembangkan.

Berdasarkan indeks kesepakatan antar penilai (inter-rater agreement) terhadap produk media bimbingan kelompok berbasis landasan hidup religius bagi siswa SMP dan petunjuk penggunaannya untuk guru BK menunjukkan skor 1 (satu). Skor ini menunjukkan bahwa menurut ahli, secara umum produk sudah tepat dengan materi yang mendasari, berguna bagi siswa, mudah dipahami, dan menarik.

Hasil skor uji kelompok kecil media bimbingan kelompok berbasis landasan hidup religius bagi siswa SMP yang dilaksanakan di SMPN 1 Papar menunjukkan skor 4,66 dari skala 1-5 yang artinya sangat baik. Siswa menilai bahwa media bimbingan kelompok berbasis landasan hidup religius bagi siswa SMP mudah dipahami dan menarik. Sementara skor uji kelompok kecil 
bagi guru menunjukkan hasil 4,32 dari skala 1-5 yang artinya sangat baik. Guru menilai media bimbingan kelompok berbasis landasan hidup religius bagi siswa SMP memiliki kebermanfaatan dan mudah diterapkan.

Saran dan masukan dari ahli adalah sebagai berikut : (1) langkah kerja guru harusnya lebih konkrit dengan kalimat aplikatif; pemilihan pengantar lebih lugas sehingga mengesankan bahasa yang "dekat" dengan siswa; (3) desain masih terkesan anak-anak, karena subyek mulai memasuki remaja, mungkin dapat disesuaikan dengan usia.

Seetelah dilakukan penilaian oleh ahli dan uji coba kelompok kecil, produk yang dihasilkan dalam penelitian pengembangan media bimbingan kelompok berbasis landasan hidup religius bagi siswa SMP ini memiliki beberapa keunggulan, antara lain: (1) media ini mampu menjadi salah satu alternatif untuk melaksanakan layanan bimbingan kelompok sebagai upaya menumbuhkan nilai religius di kalangan siswa; (2) media bimbingan ini dapat dilaksanakan dengan mudah dan efisien dalam hal waktu, dana, serta tenaga; (3) media yang digunakan fleksibel sehingga konselor dapat memaksimalkan kegiatan bimbingan sesuai dengan fasilitas yang ada di sekolah.

$$
\text { Selain }
$$

keunggulankeunggulan yang telah disebutkan di atas, produk yang dihasilkan juga memiliki beberapa kelemahan. Adapun kelemahan dari produk ini adalah: (1) belum adanya anggaran dalam pengadaan media; (2) perlu adanya pelatihan untuk melaksanakan media dalam bimbingan kelompok; (3) belum diketahui validitas berdasarka uji lapangan sehingga dalam pengaplikasiannya harus melalui penelitian tindakan.

Secara keseluruhan dapat dirumuskan bahwa pesan-pesan yang perlu dipahami mengenai landasan hidup religius dalam suatu media bimbingan dapat dirumuskan dengan baik. Hal ini dapat dilihat dari tercapainya media yang memenuhi kriteria kesesuaian dengan teori menarik dan menarik sehingga dapat digunakan untuk menumbuhkan 
sikap religius pada siswa SMP.

Tujuan untuk menghasilkan suatu media bimbingan yang dapat dipahami dan digunakan oleh siswa SMP dapat terwujud karena berdasarkan uji kelompok kecil, siswa mudah memahami isi media dan guru BK dapat menggunakan media bimbingan kelompok berbasis landasan hidup religius bagi siswa SMP dengan mudah secara aplikatif.

Bagi keilmuan bimbingan dan konseling, pengembangan media bimbingan kelompok berbasis landasan hidup religius bagi siswa SMP ini memberikan kontribusi dalam memperkaya media layanan dasar bimbingan dan konseling. Media bimbingan kelompok berbasis landasan hidup religius bagi siswa SMP dapat digunakan sebagai upaya preventif untuk mencegah lunturnya nilai religius siswa sebagai kebutuhan dasar yang harus dimiliki oleh setiap individu. Dengan demikian, kehadiran media bimbingan kelompok berbasis landasan hidup religius bagi siswa SMP ini dapat memperkaya mesia bimbingan konseling di sekolah.

\section{KESIMPULAN}

Pengembangan media bimbingan kelompok berbasis landasan hidup religius bagi siswa SMP bertujuan untuk menghasilkan sebuh produk media yang dapat diaplikasikan oleh guru BK di sekolah dalam melaksanakan layanan bimbingan kelompok. Media ini diharapkan mampu menjadi alternatif pilihan media sebagai upaya preventif menurunnya perilaku religius di kalangan siswa.

Penelitian ini menghasilkan produk akhir berupa media bimbingan kelompok berbasis landasan hidup religius bagi siswa SMP dan buku petunjuk pelaksanaannya untuk guru BK. Media yang dikembangkan berisi materi bertema religius yang disesuaikan dengan tugas perkembangan remaja sesuai dengan sasaran media. Media dikembangkan dengan bahasa yang lugas, sehingga mudah dipahami oleh siswa dan menggunakan gambar-gambar yang bertujuan untuk menarik perhatian siswa.

Berdasarkan hasil revisi, dapat disimpulkan bahwa produk 
berupa media bimbingan kelompok berbasis landasan hidup religius bagi siswa SMP layak untuk dilaksanakan dan dapat diterima oleh calon pengguna. Kelayakan produk didapat setelah melalui beberapa tahapan pengembangan yang dimulai dari analisis kebutuhan siswa hingga penilaian dari ahli media dan ahli $\mathrm{BK}$, serta hasil penilaian dari calon pengguna yaitu siswa SMP dan guru BK. Penilaian dari ahli dan calon pengguna inilah yang menjadi dasar untuk melakukan revisi produk, serta di dapat produk yang layak serta efektif secara teoritis dan praktik.

Berdasarkan penilaian ahli dan uji calon pengguna, tujuan penelitian untuk merumuskan pesanpesan yang perlu dipahami mengenai landasan hidup religius dalam suatu media bimbingan dapat dirumuskan dengan baik. Hal ini dapat dilihat dari tercapainya media yang memenuhi kriteria kesesuaian dengan teori menarik dan menarik sehingga dapat digunakan untuk menumbuhkan sikap religius pada siswa SMP.

Tujuan untuk menghasilkan suatu media bimbingan yang dapat dipahami dan digunakan oleh siswa SMP juga dapat terwujud karena berdasarkan uji kelompok kecil, siswa mudah memahami isi media dan guru BK dapat menggunakan media bimbingan kelompok berbasis landasan hidup religius bagi siswa SMP dengan mudah secara aplikatif.

\section{DAFTAR PUSTAKA}

AECT.1977.The Definition of
Educational Technology.
Washington: Association for
Educational Communication
and Technology

Ancok, Djamaludin dan Suroso, Fuat Nashori. 2005. Psikologi Islam : Solusi Islam Atas problemProblem Psikologi. Yogyakarta: Pustaka Pelajar

Borg, W.R. and Gall, M.D. 1983. Educational Research: An Introduction. London: Longman, Inc

Gregory, R.J. 2011. Psycological Testing: History, Principles and Aplications. Boston:Allyn and Bacon

Hurlock, E. B. 1999. Psikologi Perkembangan: Suatu Pendekatan Sepanjang RuangKehidupan. Edisi 5. Jakarta: Erlangga.

Jalaludin, R. 2003.Psikologi Agama. Bandung: Remaja Rosda Karya 
Mustaji, Mochammad Nursalim. 2010. Media bimbingan dan Konseling. Surabaya: Unesa Universitas press.

Purwadi. 2002. Penghayatan Keagamaan Orang Jawa. Yogyakarta : Media Pressindo Subandi. 1997. Tema-tema Pengalaman Spiritual Pengamal Dzikir. Jurnal Psikologika, II,(3) 